\title{
Evaluation of blood, biochemical and biological effects of microalgae Chlorella and germinated barley powder as a source of prebiotic on common carp Cyprinus carpio $L$.
}

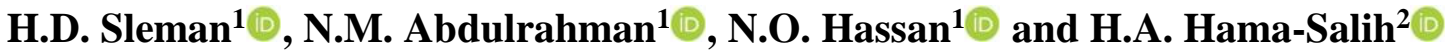 \\ ${ }^{1}$ College of Veterinary Medicine, University of Sulaimani, ${ }^{2}$ Municipality of Sulaimani, Directorate of Gardeners, \\ Sulaimaniya, Iraq
}

\begin{tabular}{l} 
Article information \\
\hline Article history: \\
Received March 10, 2020 \\
Accepted April 25, 2020 \\
Available online February 22, 2021 \\
\hline Keywords: \\
Chlorella \\
Germinated Barely \\
Common Carp \\
Blood indices \\
Blood biochemical \\
\hline Correspondence: \\
N.M. Abdulrahman \\
nasreen.lrahman@univsul.edu.iq
\end{tabular}

\section{Article information}

Article history:

Available online February 22, 2021

$$
\begin{aligned}
& \text { Germinated Barely } \\
& \text { Common Carp } \\
& \text { Blood indices } \\
& \text { Blood biochemical } \\
& \text { Correspondence: } \\
& \text { N.M. Abdulrahman } \\
& \text { nasreen.1rahman@univsul.edu.iq } \\
& \hline
\end{aligned}
$$

\begin{abstract}
This study aimed to evaluate the effects of Chlorella and germinated barley powder on the hematological and biochemical parameters of (Cyprinus carpio L.). An experiment was designed with five treatments; Groups included T1: Diet without any supplement (Control), T2: adding $5 \%$ Chlorella/ kg diet, T3: adding $10 \%$ Chlorella / kg diet, T4: adding $10 \%$ germinated barely / kg diet, T5: adding $20 \%$ germinated barely/ kg diet. At the end of the experiment, the hematological and Immunological parameters were measured. The results revealed that supplementation of Chlorella and germinated barley in diets in which T4 were higher significantly in each of hemoglobin and red blood corpuscles. T1 was significantly higher in the control. A different significance observed in each of Mean Corpuscular Hemoglobin Concentration (MCHC), Mean Corpuscular Volume (MCV), and Mean Corpuscular Hemoglobin $(\mathrm{MCH})$. Significant variants observed in differential WBC count in T2 and T4 and Monocytes \%, a significant difference seen among the treatments in each of Lymphocytes \% and Granulocytes \%. Significant differences occurred by adding the Chlorella and germinated barely in each Total protein, Alanine aminotransferase activity (ALT), Aspartate aminotransferase activity (AST), Albumin and Globulin among treatments. A significant difference observed in the Hepatosomatic index and Gillsomatic index, T5 with $20 \%$ germinated barely was differ significantly in each of Spleensomatic and Kidneysomatic Index. Based on the results, supplementation of Chlorella and germinated barley in diet can play a role in effecting on some blood and biochemical parameters.
\end{abstract}

DOI: 10.33899/ijvs.2020.126706.1364, (C2021, College of Veterinary Medicine, University of Mosul.

This is an open access article under the CC BY 4.0 license (http://creativecommons.org/licenses/by/4.0/).

\section{Introduction}

The importance of aquaculture has escalated in the past years via people's diet improvement, creating work opportunities in rural areas and changes the import through conservation of foreign exchange (1). Anderson et al. (2) stated that this growth has often increased the way of seafood generation, operated and consumed. Besides, in food industries, it has redefined the role of seafood as well. As microalgae have greater photosynthetic efficacies, greater harvests and growth rates, and required for few space of land for cultivation and have the capability to grow in salty waters and arid and barren land areas, they might demonstrate as an alternative to terrestrial crops (3).

Since 1961, the average annual increase in global apparent food fish consumption (3.2 percent) has outpaced population growth (1.6 percent) and exceeded that of consumption of meat from all terrestrial animals, combined (2.8 percent) and individually (bovine, ovine, pig, other), except poultry (4.9 percent). In per capita terms, food fish 
consumption has grown from $9.0 \mathrm{~kg}$ in 1961 to $20.2 \mathrm{~kg}$ in 2015 , at an average rate of about 1.5 percent per year. Preliminary estimates for 2016 and 2017 point to further growth to about 20.3 and $20.5 \mathrm{~kg}$, respectively. The expansion in consumption has been driven not only by increased production, but also by a combination of many other factors, including reduced wastage, better utilization, improved distribution channels and growing demand, linked with population growth, rising incomes and urbanization. Globally, fish and fish products provide an average of only about 34 calories per capita per day. However more than as an energy source, the dietary contribution of fish is significant in terms of high-quality, easily digested animal proteins and especially in fighting micronutrient deficiencies. A portion of $150 \mathrm{~g}$ of fish provides about 50 to 60 percent of an adult's daily protein requirement. Fish proteins are essential in the diet of some densely populated countries where the total protein intake is low, and are particularly important in diets in Small Island Developing States (SIDS) (4).

The protein that removed from combined or pure cultures of yeast, algae, bacteria or fungi and utilized as an alteration for the protein sources exploited for the consumption of animals and humans is called Single-cell protein (SCP), throughout the second half of the twentieth century, microalgae were a source of concern to most of those engaged in food domains agricultural sector and have been recognized as major consistent protein sources (5). The protein level of most microalga sources are larger compared to other plant or animal sources, such as Spirulina platensis which have $65 \%$ of protein content which is more than that of soy flour $(37 \%)$, dried skimmed milk $(36 \%)$, peanuts (26\%), fish (24\%), and chicken (24\%), and beef $(22 \%)(6,5)$.

Microalgae have to have a sufficient nutrient structure, and be free of poisons which may switch to the food chain (7). Tetraselmis, Chlorella, Scenedesmus, Pavlova, Nannochloropsis, Phaeodactylum, Chaetoceros, Thalassiosira, and Skeletonema are the most commonly utilized genus of microalgae in aquaculture, the microalgae have required attributes to be beneficial for aquaculture such resistance to some aquatic parameters such as fluctuation in nutrients, temperature and light, and fast growth rates (8).

The studies on Chlorella utilization in lower vertebrates were less but more focused on human food (9). Nangul and Bhatia (10) found that the high-value biological molecules main source likes polyunsaturated fatty acids, pigments and proteins were algae. Chlorella, Spirulina (Arthrospira) and Dunaliella which were the three major commercially used species for protein production, with high protein content of $55 \%, 65 \%$ and $57 \%$ correspondingly.

Barley is used for a variety of natural and novel end-uses. In some countries, the most using of barley for feeding of animals, especially in sheep, pigs and cattle. The use of barley as human food was limited, although nowadays the use of barley varieties, high in dietary fiber, has been identified. Malt was the high-value use to produce as raw ingredients for the brewing industries. An arabinoxylan-rich germinated barley product has been reported by Kanauchi $e t$ al. (11) to induce the beneficial bacteria in the human intestine. However, as for all known and emerging prebiotics, convincing evidence of a consistent clinical benefit in the treatment of Inflammatory bowel disease (IBD) remains to be demonstrated in large, randomized, double-blind, placebo-controlled studies (12).

This research aims to compare the utilization of Chlorella as a natural food items as a source of animal protein and germinated barley powder as a source of prebiotic as a food supplement to commercial feed for common carp (Cyprinus carpio) for blood indices, immunity parameters and biological indices.

\section{Materials and methods}

\section{Used fish}

The experiment was done for 70 days on 175 common carp C. carpio L. received from fish projects in Peramagrun/ Sulaimani/ Iraq (90 fish used for this experiment). Fish weight varied between (53.123 - $56.18 \mathrm{~g}$ ). Randomly fish distributed to experimental plastic tanks with mean initial weight $54.437 \mathrm{~g}$. laboratories pre-acclimation and feeding with commercial pellets.

\section{Experimental system}

Plastic tank $(70 \mathrm{~L})$ used in this trial for five treatments each with three replicates. Proper continuous aeration added to each tank by using Chinese's air compressors, Hailea ACO-318 (power: 45 watts, air flow: $70 \mathrm{~L} / \mathrm{min}$ ), Hailea ACO-328 (power: 55 watts, air flow: $82 \mathrm{~L} / \mathrm{min}$ ), Resun ACO010 (power: 200 watts, air flow: $0.135 \mathrm{~m}^{3} / \mathrm{min}$ ) and eleven small aquarium air pumps, Luckiness 828 (power: 5 watts, air flow: $3.5 \mathrm{~L} / \mathrm{min}$ ). Each replicate was stocked with six fish. The replicates will be randomly placed to reduced differences among treatments. Cleaning was made daily by using a siphon to remove feces and remained feeds from the tanks. T1: Diet without any supplement (Control), T2: adding $5 \%$ Chlorella/ kg diet, T3: adding $10 \%$ Chlorella / $\mathrm{kg}$ diet, T4: adding $10 \%$ germinated barely / kg diet, T5: adding $20 \%$ germinated barely/ $\mathrm{kg}$ diet.

\section{Diet formulation}

Experimental diets contain standard items found in Sulaimani city markets, and then enriched with Chlorella and germinated barley powder. The items were mixed to obtain dough. Then, by using of Kenwood Multi-processors for electrical mincer for pelleting and dried under room temperature for four days. Feeding twice daily at morning at 9:00 a.m. and the second at 3:00 p.m. with $3 \%$ of body weight. Bimonthly weighed for the fish and according to new weights the feeding levels were rechecked for ten weeks. 
Crude protein ratio in fish diets was $28.06 \%$ and the Gross energy ( $\mathrm{kcal} / \mathrm{kg}$ feed) was 2242.7 .

Organic Chlorella powder from (Chlorella pyrenoidosa) a product packed by Nukraft, 433 Caledonian Road, London N7 9BG, UK, the nutritional information of used Chlorella (Per 100g) were Energy $418 \mathrm{Kcal}$; Protein 55g; Fat 15g; Carbohydrate 19.5g; Fiber $12.5 \mathrm{~g}$ and Salt 0.1g. The germinated barley exported from the company Changsha Huir Biological Tech co., LTD.

Three fish were randomly chosen from each replicate at the end of the experimental period were weighed and their length taken individually then cutting the caudal peduncle to take blood samples and collected in the heparinized plastic vials and stored under cooling condition (13). All blood tests were done by using a hematological analyzing device type ACCENT 200 Poland's origin. The levels of enzymes were assayed according to the instructions provided with the corresponding enzymatic kits. Erythrocyte count (RBCs: $10^{12} \mathrm{cells} / \mathrm{L}$ ), Mean Corpuscular Hemoglobin Concentration (MCHC; g/dL), Mean Corpuscular Hemoglobin (MCH; pg), Mean Corpuscular Volume (MCV; fL), Hemoglobin (Hb; $\mathrm{g} / \mathrm{dL}$ ) and Platelet (PLT; $10^{9}$ cells/L). Differential leukocyte count $\left(10^{9}\right.$ cells $\left./ \mathrm{L}\right)$, Granulocytes \%, Lymphocytes \%, Monocytes \%. Biochemical parameters: Aspartate aminotransferase activity (AST), Total proteins, Alanine aminotransferase activity (ALT), Globulin (g/dL), Albumin $(\mathrm{g} / \mathrm{dL})(13)$.

\section{Biological indices}

After blood and serum sampling fish weigh and length were determined. Fish were dissected and liver, gills, viscera, kidney, were weighed. The organs-somatic indices of fish were calculated as Hepatic somatic index (HSI, \%) = 100 (liver weight $(\mathrm{g}) /$ fish weight $(\mathrm{g}$ ); Gills somatic index
$(\mathrm{GSI}, \%)=100$ (gills weight $(\mathrm{g}) /$ fish weight $(\mathrm{g})$; Spleensomatic index $($ SSI, \%) $=100$ (Spleen weight $(\mathrm{g}) /$ fish weight $(\mathrm{g})$; Kidney somatic index $($ KSI, \%) $=100$ (kidney weight $(\mathrm{g})$ / fish weight $(\mathrm{g})$.

\section{Statistical analysis}

The trial conducted by one way (ANOVA) with completely randomized design (CRD) and general linear models (GLM) procedure of XLSTAT 2016 Version.02.28451. Duncan's test was used to compare treatments means.

\section{Results}

Table 1 show the effect of adding a different level of Chlorella as a natural source of protein and germinated barley as a source of prebiotic in common carp blood parameters in which $\mathrm{T} 1$ (control) and $\mathrm{T} 4$ were higher significantly in each of $\mathrm{Hb}$ and $\mathrm{RBC}$. T1 was significantly higher in the control. A different significance observed in each of MCV, MCH and MCHC.

Significant differences observed in WBC count in T2 and T4 and Monocytes \% as shown in table (2), significant differences were seen in the different treatments in each of Lymphocytes \% and Granulocytes \%.

Table 3 show the significant differences that occurred by adding the Chlorella and germinated barely in each ALT, AST, Total Protein, Albumin and Globulin among treatments.

A significant difference observed in the Hepatosomatic index and Gillsomatic index as seen in the table (4), T5 with $20 \%$ germinated barely was differ significantly in each of Spleensomatic and Kidneysomatic Index.

Table 1: Effect of Chlorella and germinated barley administration on some hematological parameters of common carp

\begin{tabular}{lcccccc}
\hline Treatments & $\mathrm{Hb} / \mathrm{dL}$ & $\mathrm{RBC}^{12} 0^{12} \mathrm{cells} / \mathrm{L}$ & $\mathrm{MCV} \mathrm{fL}$ & $\mathrm{MCH} \mathrm{pg}$ & MCHC g/dL & PLT10 ${ }^{9}$ cells/L \\
\hline T1 & $94.750 \mathrm{a}$ & $0.825 \mathrm{ab}$ & $227.375 \mathrm{a}$ & $135.775 \mathrm{a}$ & $611.000 \mathrm{a}$ & $95.750 \mathrm{a}$ \\
T2 & $88.833 \mathrm{ab}$ & $0.928 \mathrm{~b}$ & $192.367 \mathrm{~b}$ & $149.883 \mathrm{a}$ & $484.100 \mathrm{bc}$ & $62.167 \mathrm{c}$ \\
T3 & $82.000 \mathrm{~b}$ & $0.797 \mathrm{c}$ & $197.817 \mathrm{ab}$ & $115.667 \mathrm{c}$ & $502.167 \mathrm{~b}$ & $66.000 \mathrm{c}$ \\
T4 & $97.000 \mathrm{a}$ & $1.000 \mathrm{a}$ & $185.683 \mathrm{c}$ & $111.483 \mathrm{c}$ & $500.500 \mathrm{~b}$ & $82.333 \mathrm{~b}$ \\
T5 & $79.333 \mathrm{~b}$ & $0.630 \mathrm{c}$ & $221.300 \mathrm{a}$ & $136.733 \mathrm{~b}$ & $621.167 \mathrm{a}$ & $84.000 \mathrm{~b}$ \\
\hline
\end{tabular}

Means in the same column with different letters represent significant differences at $P<0.05$.

Table 2: Effect of Chlorella and germinated barley on common carp WBC count and differential WBC

\begin{tabular}{lcccc}
\hline Treatments & WBC $\left(10^{9}\right.$ cells/L) & Lymphocytes $\%$ & Monocytes \% & Granulocytes \% \\
\hline T1 & $242.000 \mathrm{ab}$ & $13.425 \mathrm{ab}$ & $32.775 \mathrm{ab}$ & $53.800 \mathrm{a}$ \\
T2 & $244.267 \mathrm{a}$ & $15.533 \mathrm{ab}$ & $32.967 \mathrm{ab}$ & $51.500 \mathrm{ab}$ \\
T3 & $226.167 \mathrm{~b}$ & $11.200 \mathrm{~b}$ & $33.750 \mathrm{a}$ & $55.050 \mathrm{a}$ \\
T4 & $245.350 \mathrm{a}$ & $15.617 \mathrm{ab}$ & $33.133 \mathrm{a}$ & $50.750 \mathrm{ab}$ \\
T5 & $242.033 \mathrm{ab}$ & $27.000 \mathrm{a}$ & $30.733 \mathrm{~b}$ & $42.267 \mathrm{~b}$ \\
\hline
\end{tabular}

Means in the same column with different letters represent significant differences at $P<0.05$. 
Iraqi Journal of Veterinary Sciences, Vol. 35, No. 2, 2021 (271-277)

Table 3. Effect of Chlorella and germinated barley on common carp biochemical parameters

\begin{tabular}{lccccc}
\hline Treatments & AST $(\mathrm{IU} / \mathrm{L})$ & ALT $(\mathrm{IU} / \mathrm{L})$ & Total protein $(\mathrm{g} / \mathrm{dl})$ & Albumin $(\mathrm{g} / \mathrm{dl})$ & Globulin $(\mathrm{g} / \mathrm{dl})$ \\
\hline T1 & $366.150 \mathrm{ab}$ & $42.345 \mathrm{c}$ & $34.015 \mathrm{a}$ & $1.740 \mathrm{a}$ & $32.275 \mathrm{a}$ \\
T2 & $337.333 \mathrm{~b}$ & $42.763 \mathrm{c}$ & $32.153 \mathrm{a}$ & $1.587 \mathrm{ab}$ & $30.558 \mathrm{a}$ \\
T3 & $549.067 \mathrm{ab}$ & $67.385 \mathrm{ab}$ & $32.542 \mathrm{a}$ & $1.728 \mathrm{a}$ & $30.767 \mathrm{ab}$ \\
T4 & $701.900 \mathrm{a}$ & $75.458 \mathrm{a}$ & $32.888 \mathrm{a}$ & $1.665 \mathrm{a}$ & $31.218 \mathrm{a}$ \\
T5 & $402.175 \mathrm{ab}$ & $47.210 \mathrm{bc}$ & $31.013 \mathrm{ab}$ & $1.650 \mathrm{a}$ & $29.360 \mathrm{ab}$ \\
\hline
\end{tabular}

Means in the same column with different letters represent significant differences at $P<0.05$.

Table 4: Effect of microalgae Chlorella and germinated barely on common carp physio-biological indices after a rearing experiment for 70 days

\begin{tabular}{lcccc}
\hline Treatments & Hepatosomatic index & Gillsomatic index & Spleensomatic index & Kidneysomatic Index \\
\hline T1 & $2.112 \mathrm{ab}$ & $3.570 \mathrm{ab}$ & $0.223 \mathrm{ab}$ & $0.573 \mathrm{ab}$ \\
T2 & $2.573 \mathrm{a}$ & $3.088 \mathrm{ab}$ & $0.103 \mathrm{~b}$ & $0.562 \mathrm{ab}$ \\
T3 & $1.709 \mathrm{ab}$ & $4.223 \mathrm{a}$ & $0.249 \mathrm{ab}$ & $0.461 \mathrm{~b}$ \\
T4 & $2.695 \mathrm{a}$ & $3.054 \mathrm{ab}$ & $0.288 \mathrm{ab}$ & $0.405 \mathrm{~b}$ \\
T5 & $2.685 \mathrm{a}$ & $3.022 \mathrm{ab}$ & $0.432 \mathrm{a}$ & $0.675 \mathrm{a}$ \\
\hline
\end{tabular}

Means in the same column with different letters represent significant differences at $P<0.05$.

\section{Discussion}

In this study different levels of Chlorella and germinated barley powder were added in the diet of Common carp and examine their effects on the blood, and biochemical parameters were detected. In the experiment observed that the use of Chlorella in diets as $5 \%$ and $10 \%$, it was not affected on some blood parameters such as ( $\mathrm{Hb}, \mathrm{RBC}$ and WBC) compare within control. But, Khani et al. (14), observed in there reports that adding of Chlorella resulted in higher levels of red blood corpuscles (RBC), hemoglobin (Hb) and white blood cells (WBC) which agree with our result. The being of Chlorella can play a potential role in the enhancement of the fish immune system. Such stimulation can make fish to be more resistant to both unsuitable environmental conditions and outbreaks of infectious diseases (15).

Using algae as a feed supplement to fish changed the biological indices studied, Hepatosomatic index in all treatments were different significantly compared to control group, the Spleenosomatic index in control and T4 were higher significantly than others, in Gillsomatic index the T2 and T4 significantly differed, while T4 was significantly higher than other treatments in Kidneysomatic index. Fish weight indices such as weight without viscera and weight without viscera and head significantly differ in the treatments with the supplements of Chlorella the diet (16).

Abid (17) showed that WBC and lymphocytes were higher significantly in $\mathrm{T} 2(2.5 \mathrm{~g}$ Chlorella/ $\mathrm{kg}$ diet $)$ than other treatments, monocytes and granulocytes in control and T4 (7.5 g Chlorella/ kg diet) were significantly higher than other treatments, the control and T2 were lower significantly than others. RBC and $\mathrm{HB}$ were higher significantly in each of T3 (5 g Chlorellal $\mathrm{kg}$ diet) and T4, HCT differ significantly among treatments in $\mathrm{T} 4$ as compared to other treatments. MCV and $\mathrm{MCHC}$ were higher significantly in $\mathrm{T} 2$ and T3.

Yildiz et al. (18) and Yu et al. (19) suggest that enhancement of serum protein level is a vital factor for changing the immunity of a fish. Within the immune cell characteristics, the RBC are the main used parameter to evaluate possible effects (anemia) induced by immunostimulant addition in supplemented feed; WBCs are the immune-competent cells of the immune system which play great roles to both infectious and non-infectious diseases (20).

An enhancement in the WBC population size was seen in fish fed Chlorella at different concentrations. Such enhancement is in part be due to the positive effects of some ingredients of Chlorella e.g. vitamins and glucans available in the cell wall of Chlorella, Therefore, the inclusion of Chlorella in the fish feed can provide a stimulatory role for the fish immune status i.e. increasing in phagocytosis capacity and cell-mediated immune responses increasing the fish resistance to the diseases and disorders $(21,22)$.

Therefore, an improvement in these immune parameters suggests a positive role of Chlorella administration (up to $10 \%$ of the diet) on the mucosal immunity of fish (23). Physiologically, $\mathrm{Hb}$ and $\mathrm{HCT}$ are crucial to the survival of fish, being directly related to the oxygen-binding capacity of blood (24). Obviously under such conditions the animal metabolism is improved resulting in a better growth performance (14).

Chlorella can be considered as a good choice as a supplement and additive for fish diets. Because of high levels of crude protein, it possesses a significant concentration of polysaccharides, lipids, minerals and other bioactive 
components involved in many physiological activities $(9,14)$.

The cholesterol and triglyceride concentration of fish serum fed 5\% Chlorella were lower $(P<0.05)$ than the control group fish. The ALT and AST of fish in different groups had the normal level $(P>0.05)$ pattern. Fish fed 2\% Chlorella showed the most significant differences in each of the cholesterol and triglyceride levels (17). Al-Koye (13) showed that replacing fishmeal with 10, 15, $20 \%$ Spirulina in 200 fingerlings common carp (C. carpio) diet for 105 days, increased blood parameters ( $\mathrm{HB}, \mathrm{MCH}, \mathrm{MCHC}, \mathrm{MCV}$, and PLT) than other treatments where fish fed with replacing $(0,5 \%$ Spirulina $)$, significant differences $(P \leq 0.05)$ seen in all treatments in RBCs and they agree with the present results.

Thirty percentage of microalgae production was used for animal feed purposes, according to the increasing demand for food with natural composition instead of synthesized ingredients (25). With regards to Chlorella vulgaris which contains an important amount of carotenoids and other nutrients (considered as a nutrient-dense superfood) and after feeding it to fish, it resulted in pigmentation potential for fish flesh, together with enhancing health and increasing its life expectancy $(26,27)$.

Hematological parameters are influenced by species, age, sexual maturity, health condition, nutritional quality of the target fish and the environmental conditions (24). RBC in teleost is related to the oxygen requirement (28). For evaluating possible undesired collateral impacts (anemia) motivated by immunostimulants managed in supplemented feed, RBC count is a normally utilized parameter among the immune cell parameters (20). The activity of innate immune parameters can be impacted by several internal and external factors. While several food additives and immunostimulants might improve various innate factors, temperature alterations, stress handling and crowding might have suppressive impacts on innate parameters. Physiologically, $\mathrm{Hb}$ is vital for fish survival, being straightly associated with the blood capacity in oxygen binding (24). Obviously under such conditions the animal metabolism is improved resulting in a better growth performance (14). The results demonstrated that for fish diets, Chlorella could be a decent choice as feed additive due to the significant level of minerals, polysaccharides, lipid and other bioactive components related to several physiological activities Because of high levels of crude protein, $(9,14)$.

Baiz's (29) study the hematological parameters were not different significantly $(P \leq 0.05)$ of all treatments in red blood cells (RBCs). The data regarded of hemoglobin (Hb), T5 diet with $50 \mathrm{~g}$ Daphnia $/ \mathrm{kg}$, T3 diet with $50 \mathrm{~g}$ Chlorella $/ \mathrm{kg}$ and $\mathrm{T} 4$ diet with $25 \mathrm{~g}$ Daphnia $/ \mathrm{kg}$ were higher respectively than other treatments significantly $(P<0.05)$. Among all the treatments, the $\mathrm{MCH}, \mathrm{MCV}$, and $\mathrm{MCHC}$ values were not different $(P \leq 0.05)$ significantly. The Platelets (PLT) for the T7 diet with $50 \mathrm{~g}$ Chlorella $+50 \mathrm{~g}$ Daphnia/ $\mathrm{kg}$ and T5 diet with $50 \mathrm{~g}$ Daphnia $/ \mathrm{kg}$ were different significantly $(P \leq 0.05)$ from other dietary treatments.

The adding of Spirulina to fish diets in different levels leads to differences in differential WBC counts (Lymphocytes, Monocytes, and granulocytes), $\mathrm{Hb}$, cholesterol, Triglyceride, spleenosomatic index, these results revealed that the dietary addition of both algae Spirulina and Chlorella could enhance immune response (30) as observed with the recent results.

Al-Amili, (31) found that the germinated barley powder as a source of prebiotic was significantly different in each of $\mathrm{RBC} \mathrm{Hb}$, and PCV and this was agreed with the results of (32) in using FOS powder as a source of prebiotic in differential WBC. The results of the recent study agree with that of (31) in the studied biological parameters such as Hepatosomatic, Spleensomatic, Gillsomatic and Kidneysomatic indices. And found a significant difference among treatments with germinated barely showing an enhancement of common carp immunity parameters. According to the results of (33) a significant differences observed among the treatments than the control in RBC counts, $\mathrm{Hb}$ and $\mathrm{PCV}$. In general Barley sprout powder $(5 \mathrm{~g} /$ $\mathrm{kg}$ diet) was higher numerically than other treatments, especially if compared with control and hydroponic planting in both levels, the significant analysis of the Lymphocyte data shown no significance; in Heterotroph all the treatments were significantly differ than T7 Natural planting $5 \mathrm{gm} / \mathrm{kg}$ diet. Control treatment was higher significantly than other treatments in $\mathrm{H} / \mathrm{L}$ ratio. According to literature review no nearby research could be obtained so no comparison with previous data could be done to more explain of the present results.

In order to contribute to health or well-being, the impact of probiotics by enhancing immunity and improving disease tolerance in fish was used to enable fish to use metabolic energy to combat the effect of environmental stress (34), and since the probiotic consists of harmless microorganism cells in this material, they consider direct benefits to the host as immunostimulants and our findings are in agreement with (35) who pointed that probiotics improved the blood picture of common carp when fed on a meal containing Poultrystar® of $(1 \mathrm{~g} / \mathrm{kg}$ body weight.

\section{Conclusion}

Using of natural products such as the algae and barely can enhance fish performance leading to good immunity.

\section{Acknowledgments}

The authors would like to thanks the college of veterinary medicine for their help, special thanks to Dr. Hemn Nuralldin for doing the statistical analysis. 


\section{Conflict of interest}

The authors declare that there are no conflicts of interest regarding the publication of this manuscript.

\section{References}

1. Adewumi A. Growth performance and survival of Clarias gariepinus hatchlings fed different starter diets. Europ J Exper Biol. 2015;5(3):15. [available here]

2. Anderson J, Asche F, Garlock T, Chu J. Aquaculture: Its role in the future of food. Front Econ Global. 2017;17:159-173. [available here]

3. Lakaniemi A, Hulatt C, Thomas D, Tuovinen O, Puhakka. Biogenic hydrogen and methane production from Chlorella vulgaris and Dunaliella tertiolecta biomass. Biotechnol. 2011;4:34. [available here]

4. FAO. The State of World Fisheries and Aquaculture 2018 - Meeting the sustainable development goals. Rome. Licence; 2018. 227 p. [available herel

5. Barka A, Blecker C. Microalgae as a potential source of single-cell proteins. A review. Biotech Agron Soc Environ. 2016;20(3):427-436. [available here]

6. Moorhead K, Capelli B, Cysewski G. Spirulina Nature's Superfood. $3^{\text {rd }}$ ed. Cyanotech Corporation, Hawaii, USA; 2011. 66 p. [available here]

7. Brown R. Nutritional Value of Microalgae for Aquaculture. 3-6 September 2002. Mexico; 2002. 281-292 p. [available here]

8. Sirakov I, Velichkova K, Stoyanova S, Staykov Y. The importance of microalgae for the aquaculture industry. Review. Internat J Fish Aquat Stud. 2015;2(4):81-84. [available here]

9. Xu W, Gao Z, Qi Z, Qiu M, Peng J, Shao R. Effect of dietary Chlorella on the growth performance and physiological parameters of Gibel carp, Carassius auratus gibelio. Turk J Fish Aquat Sci. 2014;14:53-57. Doi: $\underline{10.4194 / 1303-2712-v 14 \quad 107}$

10. Nangul A, Bhatia R. Microorganisms: A marvelous source of singlecell proteins. J Micro Biotech Food Sci. 2013;3(1):15-18. [available herel

11. Kanauchi O, Iwanaga T, Mitsuyama K. Butyrate from bacterial fermentation of germinated barley foodstuff preserves intestinal barrier function in experimental colitis in rats. J. Gastroenterol Hepatol. 1999;14:880-8. Doi: 10.1046/j.1440-1746.1999.01971.x

12. Gibson GR, Rastall RA. Prebiotics: Development and Application. England: John Wiley and Sons Ltd; 2006. 231 p. [available here]

13. Al-Koye H. Effect of Using Spirulina spp. Instead of fishmeal on growth, blood picture and microbial load of common carp Cyprinus carpio [MSc Thesis]. Erbil: College of Agriculture, University of Salahaddin, Erbil, Iraq; 2013. [available here]

14. Khani M, Soltani M, Mehrjan MS, Foroudi F, Ghaeni M. The effect of Chlorella vulgaris (Chlorophyta, Volvocales) microalga on some hematological and immune system parameters of Koi carp (Cyprinus carpio). Iran J Ichthyol. 2017;4(1):62-68. [available here]

15. Turner JL, Dritz SS, Higgins JJ. Effects of Ascophyllum nodosum extract on growth performance and immune function of young pigs challenged with Salmonella typhimurium. J Anim Sci. 2002;80(7):1947-1953. Doi: $10.2527 / 2002.8071947 \mathrm{x}$

16. Abdulrahman NM, Abid SH, Khidir AA, Omer BB, Hama Rasheed DB, Baha Alddin LH. Effect of adding microalgae Chlorella sp. on some biological parameters and proximate analysis of common carp Cyprinus Carpio L. Iran J Vet Med. 2018;12(3):199- 205. Doi: 10.22059/IJVM.2018.244747.1004856

17. Abid SH. Physiological effect of microalgae chlorella sp. on the common carp (Cyprinus carpio L.) [MSc thesis]. Turkey: Institute Of Science, Bingöl University, Republic of Turkey; 2017. 90 p. [available herel

18. Yildiz FH, Liu XS, Heydorn A, Schoolnik GK. Molecular analysis of rugosity in a vibrio cholera O1 El Tor phase variant. Mol Micro. 2002;53:497-515. Doi: 10.1111/j.1365-2958.2004.04154.x
19. Yu J, Starr DA, Wu X, Parkhurst SM, Zhuang Y, Xu R, Han M. The KASH domain protein MSP-300 plays an essential role in nuclear anchoring during Drosophila oogenesis. Develop Biol. 2006;289(2):336-345. Doi: 10.1016/j.ydbio.2005.10.027

20. Morera D, Roher N, Ribas L, Balasch JC, Doñate C, Callol A, Boltaña S, Roberts S, Goetz G, Goetz FW, MacKenzie SA. RNA-Seq reveals an integrated immune response in nucleated erythrocytes. PLOS ONE. 2011;6(10):e26998. Doi: 10.1371/journal.pone.0026998

21. Monter RA, Mcintosh D, Sanchez MR, Flores I. Immunostimulation of white shrimp (Litopenaeus vannamei) following dietary administration of Ergosan. J Invert Path. 2005;9:188-194. Doi: 10.1016/j.jip.2005.12.004

22. Parra D, Reyes-Lopez FE, Tort L. Mucosal immunity and B cells in teleosts: Effect of vaccination and stress. Immunol. 2015;6:1e12. Doi: 10.3389/fimmu.2015.00354

23. Magnadottir B. Innate immunity of fish: Overview. Fish Shellfish Immun. 2006;20:137-151. Doi: 10.1016/j.fsi.2004.09.006

24. Bielek E, Strauss B. Ultrastructure of the granulocytes of the South American lungfish, Lepidosiren paradoxa: Morphogenesis and comparison to other leucocytes. J Morph. 1993;218(1):29-41. Doi: $\underline{10.1002 / \text { jmor. } 1052180103}$

25. Becker E. Micro-algae as a source of protein. Biotechnol Adv. 2007;25:207-210. Doi: 10.1016/j.biotechadv.2006.11.002

26. Gouveia L, Choubert G, Pereira N, Santinha J, Empis J, Gomes E. Pigmentation of gilthead seabream, Sparus aurata (L. 1875), using Chlorella vulgaris (Chlorophyta, Volvocales) microalga. Aquac Res. 2002;33:987-93. Doi: 10.1046/j.1365-2109.2002.00751.x

27. Gouveia L, Gomes E, Empis J. Potential use of microalgae (Chlorella vulgaris) in the pigmentation of rainbow trout (Oncorhynchus mykiss) muscle. Zeitschrift für Lebensmittel-Untersuchung und Forschung. 1999;202:75-9. [available here]

28. Zanjani ED, Contrera JF, Brown AS, Cooper GW, Wong KK, Katz R. The renal erythropoietic factor (REF). III. Enzyme role in erythropoietin production. Exp Biol Med. 1967;125(2):505. Doi: 10.3181/00379727-125-32132

29. Baiz AI. Utilization of Chlorella and Daphnia as natural food sources and their combination as a feed supplement compared to commercial feed for common carp (Cyprinus carpio) [MSc thesis]. Turkey: Institute of Natural and Applied Sciences, Van Yuzuncu Yil University, Turkey; 2018. [available here]

30. Abdulrahman NM, Hama HJ, Hama ShR, Hassan BR, Nader PJ. Effect of microalgae Spirulina spp. as food additive on some biological and blood parameters of common carp Cyprinus carpio L. Iraqi J Vet Sci. 2019;33(1):27-31. Doi: 10.33899/ijvs.2019.125527.1049

31. Al-Amili HA. Effect of different levels of earth apple and germinated barley on growth performance and some blood picture measurement of common carp Cyprinus carpio L [PhD dissertation]. Anbar: College of Agriculture, University of Anbar. 2017; 120 pp. [available here]

32. Abdulrahman NM, Ahmed VM. Comparative effect of probiotic (Saccharomyces cerevisiae), prebiotic (fructooligosaccharides FOS) and their combination on some differential white blood cells in young common carp (Cyprinus carpio L.). Asian J Sci Tech. 2015;6:11361140. [available here]

33. Abedalhammed HS, Abdulrahman NM, Sadik HL. Comparative study of the effect of natural planting, hydroponic germination and barley sprout powder as prebiotic in common carp Cyprinus carpio L. blood indices. Iraqi $\mathrm{J}$ Vet Sci. 2017;31(1):7-11. Doi: 10.33899/ijvs.2017.126704

34. Mohammad MA. Effect of adding different levels of cinnamon (Cinnamomum sp) on growth and chemical composition criteria of common carp Cyprinus carpio L. Iraqi J Vet Sci. 2021;35(1):93-98. Doi: 10.33899 /ijvs.2020.126362.1308

35. Ismail RH, Al-Hamdani AH. Effect of probiotic (Poultrystar ${ }^{\circledR}$ ) and heat stress on some blood parameters in common carp (Cyprinus carpio L.). $\begin{array}{llll}\text { Iraqi J Vet Sci. 2019;33(2):221-225. Doi: } & \end{array}$ 10.33899/ijvs.2019.125539.1061 


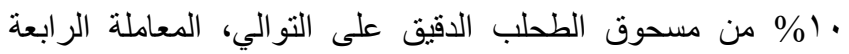

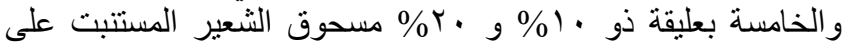

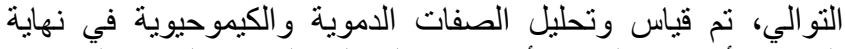

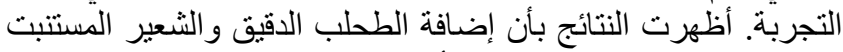

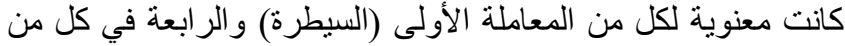

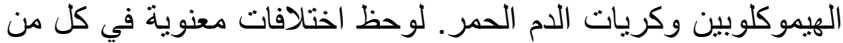

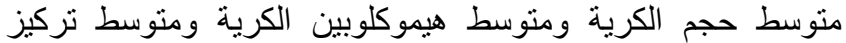

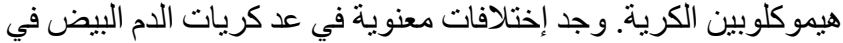

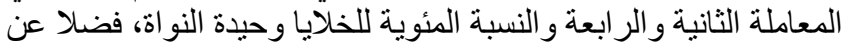

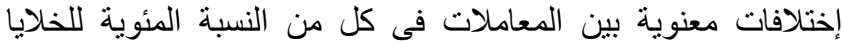

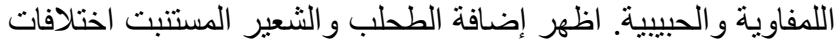

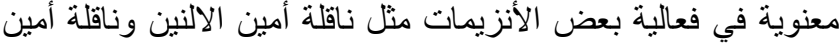

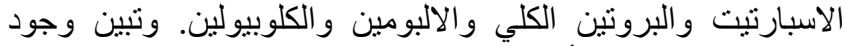

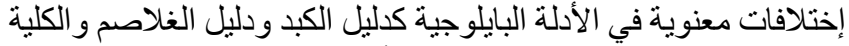

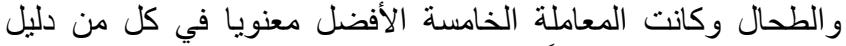

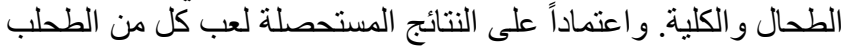

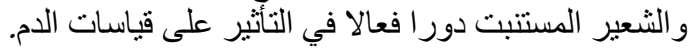

تقييم التأثيرات الاموية والكيموحياتية والبايلوجية للطحلب الاقيث Chlorella المستبت كمصدر للسابق الحيوي في أسماك الكارب الاعتيادي

هافان داود سليمان' ، نسرين محي الدين عبدالرحمن'، نازنين عثمان

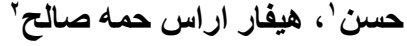

' كلية الطب البيطري، جامعة السليمانية، ‘ وزارة البلديات، السليمانية،

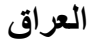

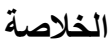

هدفت هذه الدر اسة الى تقييم استخدام الطحلب الدقيق ومسحوق الثعير

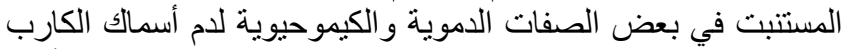

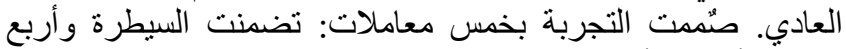

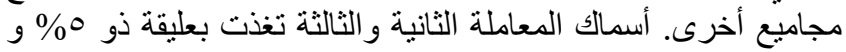

